\title{
Doctor's Responsibility in Providing Telemedicine Services among Health Care Facilities: Legal and Professional Dimensions
}

\author{
Radian Pandhika \\ radian.pandhika@yahoo.co.id \\ Alodokter, Indonesia \\ Muhammad Fakih \\ fakihugm@gmail.com \\ Universitas Lampung, Indonesia
}

Submitted: 19 January 2021; Reviewed: 25 February 2021; Accepted: 29 March 2021

\section{Article's Information}

Abstract

Keywords: Doctor's; Responsibility;

Telemedicine; Legal.

DOI:

https://doi.org/10.25041/aelr.v2i1.2251
To provide specialist health care closer and improve quality in health care facilities, especially for remote areas, the central government utilizes information and communication technology through telemedicine services among health care facilities. This matter is regulated in the Ministry of Health Regulation No. 20 Tahun 2019 tentang Penyelenggaraan Telemedicine Antar Fasilitas Pelayanan Kesehatan. This article aims to describe the forms of legal responsibility and professional responsibilities of doctors in telemedicine services among health care facilities. The method used in this study is normative juridical. The study results show that physicians' responsibilities in telemedicine services among health care facilities can be divided into legal responsibilities (which are divided into civil, criminal, and administrative) and professional responsibilities (ethics and discipline). Doctors' responsibility in telemedicine services among health care facilities is an obligation that doctors must fulfill because obligations 
are nothing but part of the tasks carried out in a particular work environment.

\section{A. Introduction}

Indonesia is a developing country and is also one of the largest archipelagic countries. The problem of even distribution of health services remains a tremendous challenge, especially in remote areas with the increasing number of people, the more and more various types of diseases that can be suffered due to an unhealthy lifestyle. This has also led to an increase in health services, especially specialist health services. Evenly distributed specialized health services are needed because remote areas also have several complex cases of a disease that require specialized health services. ${ }^{1}$ In 2019 , the number of specialist doctors registered in Indonesia was 31,073 people. The ratio of specialist doctors per population is 11.64 per 100,000 population. This ratio has exceeded the target ratio set by the Decree of the Minister of the Economy on People's Welfare Number 54 of 2013, which targets the ratio of specialist doctors in 2019 to be 11 per 100,000 population. However, there are significant differences between provinces in Indonesia. Large provinces have a higher ratio of specialist doctors, while provinces in the eastern region have a low ratio of specialist doctors. The Minister of Health also stated that an imbalance in the distribution of specialist doctors also occurred between districts within the province. Remote areas in the district had not received health services from specialist doctors. ${ }^{2}$

To improve specialist health services and service quality at health care facilities (fasyankes), especially in remote areas, the central government makes efforts to utilize information and communication technology, especially in the health sector, by establishing telemedicine services between health facilities. Telemedicine is a form of long-distance health service between medical personnel by utilizing internet technology. This health service allows medical personnel to exchange information to make diagnoses, provide management, provide education on disease prevention, even as material for research and continuing education. Telemedicine can also improve communication and collaboration between doctors because they can quickly consult and exchange experiences. ${ }^{3}$

Apart from having many benefits, the existence of telemedicine cannot be separated from obstacles. Examples include lack of infrastructure, human factors, complex culture, lack of support for business development, software or hardware failure. ${ }^{4}$ Besides, telemedicine services between health facilities can potentially lead to legal problems such as malpractice, data security issues, licensing and accreditation issues, ${ }^{5}$ and inadequate regulatory issues. Not to mention, telemedicine services are also vulnerable to ethical problems and doctor's discipline. ${ }^{6}$, Medical practice, seen from a legal perspective, is a concrete legal action that

\footnotetext{
${ }^{1}$ Andreasta Meliala, Krishna Hort, and Laksono Trisnantoro, "Addressing the Unequal Geographic Distribution of Specialist Doctors in Indonesia: The Role of the Private Sector and Effectiveness of Current Regulations," Social Science and Medicine 82 (April 1, 2013): 30-34, https://doi.org/10.1016/j.socscimed.2013.01.029.

2 Biro Komunikasi dan Pelayanan Masyarakat Sekretariat Jenderal Kementerian Kesehatan RI. (2017). Menkes Soroti Masalah Maldistribusi Dokter Spesialis di Indonesia, available online from: https://www.depkes.go.id/article/print/17022400008/menkes-soroti-masalah-maldistribusi-dokter-spesialis-indonesia.html, diakses pada November 11, 2019.

${ }^{3}$ Seewon Ryu, "Telemedicine: Opportunities and Developments in Member States: Report on the Second Global Survey on EHealth 2009 (Global Observatory for EHealth Series, Volume 2)," Healthcare Informatics Research 18, no. 2 (2012): 153, https://doi.org/10.4258/hir.2012.18.2.153.

${ }^{4}$ N. M. Hjelm, "Benefits and Drawbacks of Telemedicine," Journal of Telemedicine and Telecare (SAGE PublicationsSage UK: London, England, March 1, 2005), https://doi.org/10.1258/1357633053499886.

${ }^{5}$ Benedict Stanberry, "Legal and Ethical Aspects of Telemedicine," Journal of Telemedicine and Telecare 12, no. 4 (June 1, 2006): 166-75, https://doi.org/10.1258/135763306777488825.

${ }^{6}$ Clemens Scott Kruse et al., "Evaluating Barriers to Adopting Telemedicine Worldwide: A Systematic Review," Journal of Telemedicine and Telecare (SAGE Publications Ltd, January 1, 2018), https://doi.org/10.1177/1357633X16674087.
} 
must be held accountable by legal subjects, be it a doctor (naturist person) and hospital or clinic (recht person). This responsibility is the anticipation of malpractice and maladministration. ${ }^{7}$

Doctors as medical personnel who play a role in health services are required to be professionals in carrying out their duties and authorities and telemedicine services. Since health services between health facilities via telemedicine are relatively new and are still developing in Indonesia, the question arises, what is the responsibility of doctors if they do something detrimental to patients seen from the legal and professional dimensions in telemedicine services between health facilities? Based on these problems, it is necessary to further study doctors' responsibilities in telemedicine services between health facilities. This study method uses a normative juridical approach by collecting data from legislation, books, journals, legal publications on the internet, and other relevant materials.

\section{B. Discussion}

\section{Legal Responsibilities of Doctors in Telemedicine Services between Health Care Facilities}

Everyone must be able to be responsible for their actions or deeds. "Responsible" "is defined as "bound" and "responsibility" (aansprakelijik) in the legal sense means "attachment". ${ }^{8}$ Responsibility is part of an obligation that must be fulfilled because the obligation is nothing but part of the duties carried out in a particular work environment. The legal responsibility of doctors in telemedicine services between health facilities means that if a doctor is carrying out his profession, if he does something detrimental to others, the doctor must be accountable for what he has done and accept lawsuits for his actions.

Based on this, the following is the legal responsibility of a doctor for legal services of doctors in telemedicine services between health facilities, which are:

a. Doctor's civil liability

The legal relationship between doctors and patients is in a civil relationship, namely engagement. The doctor-patient relationship can be achieved well if the doctor and patient understand their rights and obligations and understand the applicable laws and regulations. ${ }^{9}$ Civil liability can be based on two things, responsibility based on default and actions against the law.

A doctor in running telemedicine services betwee

$\mathrm{n}$ health facilities can default, if the doctor does not do something that according to the agreement is obligatory, is late in doing something that has been agreed upon, is imperfect to do something that has been agreed upon, and does something that should not have been done. ${ }^{10}$

Default by the consultant, who is generally a specialist doctor or sub-specialist, can occur if the doctors cannot fulfill their obligations based on a contract or agreement. Cases of default committed by doctors as consultants in telemedicine services between health facilities, such as when the doctor providing the consultation have included his practice schedule at the appointed hour. However, the doctor is not present or responds to the doctor requesting

\footnotetext{
${ }^{7}$ V. J. Smith et al., "Implementation of a Fetal Ultrasound Telemedicine Service: Women's Views and Family Costs," BMC Pregnancy and Childbirth 21, no. 1 (December 1, 2021), https://doi.org/10.1186/s12884-020-03532-4.

${ }^{8}$ Munandar Wahyudin Suganda. Hukum Kedokteran. Bandung: Alfabeta. (2017). pg. 165.

${ }^{9}$ Haryanto Njoto, "PERTANGGUNGJAWABAN DOKTER DAN RUMAH SAKIT AKIBAT TINDAKAN MEDIS YANG MERUGIKAN DALAM PERSPEKTIF UU No 44 Th 2009 TENTANG RUMAH SAKIT,” DiH: Jurnal Ilmu Hukum 7, no. 14 (August 1, 2011): 57-71, https://doi.org/10.30996/dih.v7i14.263.

10 Endang Kusuma Astuti, "TANGGUNG GUGAT DOKTER DAN RUMAH SAKIT KEPADA PASIEN PADA KEGAGALAN PELAYANAN MEDIS DI RUMAH SAKIT," Masalah-Masalah Hukum 40, no. 2 (April 19, 2011): 164-71, https://doi.org/10.14710/mmh.40.2.2011.164-171.
} 
consultation during these practice hours. Instead, they only reply after a long time, so this is included in default because it is too late to do what was promised. ${ }^{11}$

The doctor, as the party requesting a consultation, which is a general practitioner, can also default in telemedicine services between health facilities. The default can occur if the doctors do not fulfill their obligations based on an agreement or contract. Cases of default committed by doctors as requesters for consultation in telemedicine services between health facilities, such as convoluted grammar or delivery methods, results of X-rays or Electrocardiogram that are unclear and blurry, making it difficult for the consultant to provide expertise on the results of supporting examinations, enforcing diagnosis, and provide therapy in consented patients. From this incident, including default, the doctor has made treatment according to his obligatory but imperfect agreement and did what according to the agreement should not be done. ${ }^{12}$

It is different from the doctor's legal responsibility because of default, whose claim for compensation is based on an agreement. In contrast, the doctor's legal responsibility for acts against the law (onrechtmatige daad) does not have to be based on an agreement. Based on Article 1365 of the Civil Code states that every act that violates the law and brings harm to others obliges the person who caused the loss because of his mistake to compensate for the loss. Accountability for acts against the law is based on the doctor having acted against the law because his actions were against the principles of appropriateness, thoroughness, and caution.

Negligence or carelessness in practicing medicine shows that there is behavior that is not following the standard stipulated by law. Even though the telemedicine service between health facilities is only through cyberspace, however, its application must be carried out with the principle of prudence in its implementation. A doctor can make mistakes in negligence or careless attitude, which leads to patient losses.

b. Doctor's legal liability in a criminal manner

Criminal liability for a doctor is based on the theory of error. Criminal liability can be asked if the doctor is proven to have made a medical error, such as a doctor who made a wrong diagnosis, resulting in errors in treatment. Mistakes or omissions are always related to the nature of being against the law. An act can be called a medical error if it has fulfilled the formulation of a criminal offense. That is, the act must be a disgraceful act and carried out with the wrong mental attitude, in the form of deliberate action, carelessness, or negligence. ${ }^{13}$ Therefore, his actions can be held responsible for the crime.

There have been no criminal cases committed by doctors in telemedicine services between health facilities, especially in Lampung Province. So far, there have been no legal cases related to telemedicine services between health service facilities. Indeed many potential medical errors can occur in telemedicine services. However, the most significant potential for medical errors in telemedicine services among health facilities is related to medical secrets. In telemedicine, many patient data cannot be leaked or misused by other parties.

Aspects of patient confidentiality will have an impact on aspects of criminal law. Based on Article 322 of the Criminal Code, anyone who deliberately opens a secret that should be

\footnotetext{
11 Yussy A. Mannas, "Hubungan Hukum Dokter Dan Pasien Serta Tanggung Jawab Dokter Dalam Penyelenggaraan Pelayanan Kesehatan," Jurnal Cita Hukum 6, no. 1 (June 23, 2018): 163-82, https://doi.org/10.15408/JCH.V6I1.8274.

12 I Gusti Ayu Apsari Hadi, "PERBUATAN MELAWAN HUKUM DALAM PERTANGGUNGJAWABAN DOKTER TERHADAP TINDAKAN MALPRAKTIK MEDIS,” Jurnal Yuridis 5, no. 1 (August 2, 2018): 98-133, https://doi.org/10.35586/.V5I1.318.

${ }^{13}$ Endang Kusuma Astuti, Transaksi Terpeutik Dalam Upaya Pelayanan Medis di Rumah Sakit, Bandung: Citra Aditya Bakti, (2009), pg. 93.
} 
kept is subject to imprisonment or a fine. ${ }^{14}$ Suppose it is connected to telemedicine services between health facilities. In that case, the doctor must keep all secrets starting from the history (medical interview), supporting files (images/video/audio) relating to patient complaints, providing comparative diagnoses, to drug recommendations to patients is a doctor's obligation to keep it confidential. This is also confirmed in Article 17 and Article 18 of the Ministry of Health Regulation No. 20 of 2019 concerning the Implementation of Inter-Health Telemedicine Services, which states that the obligation for facilitators who provide and request consultations in carrying out telemedicine services should maintain the confidentiality of patient data.

The criminal liability in telemedicine services between health facilities can be asked if the doctor has made a mistake or negligence. Of course, this responsibility must be proven first whether or not the doctor made a mistake or negligence, and the judge will determine whether the doctor is wrong or not. This offense is a complaint offense (klacht delict), so that the case cannot be continued without a complaint from the person who feels aggrieved.

c. Doctor's legal responsibility administratively.

The relationship between patient and doctor is inseparable from a sense of responsibility based on professional obligations, thus creating legal responsibility. The doctor's responsibility in administrative law is the doctor's responsibility, which relates to the administrative requirements related to the doctor's authority in carrying out the medical practice. ${ }^{15}$ Administrative law in health services is based on Article 36 of Law Number 29 of 2004 concerning Medical Practice, which states that every doctor who practices medicine in Indonesia is required to have a practice license.

Article 2 of Ministry of Health Regulation No. 20 of 2019 concerning the Implementation of Inter-Health Telemedicine Services also states that telemedicine services must have a practice permitted at the organizing facility. In running telemedicine services between health facilities, doctors must have requirements such as a registration certificate, a license to practice at the health facility. They must also be registered in the telemedicine service application registered at the Ministry of Health. ${ }^{16}$ Violations against administrative law include running practice without permission, taking medical actions that do not follow the permits they have, practicing using expired permits, and not making medical records. Violation of administrative law in medical practice is a violation of the administrative-legal obligations of medical practice.

For administrative violations, the sanctions that can be given are the issuance of written warnings, recommendations for revocation of registration certificates or practice licenses, and/or the obligation to attend education or training at medical education institutions.

Besides, things that need to be considered are doctors' responsibilities in administrative law related to telemedicine services between health facilities, namely medical records. Following Article 46 of Law no. 24 of 2009 concerning Medical Practice, which states that in carrying out a medical practice, a doctor must make patient medical records. Article 2 of Minister of Health Regulation No. 269 of 2008 concerning Medical Records states that medical records must be written, complete, and clear or electronically. This is also confirmed

\footnotetext{
${ }^{14}$ Valeri M P Siringoringo, Dewi Hendrawati, and R Suharto, "PENGATURAN PERLINDUNGAN HUKUM HAK-HAK PASIEN DALAM PERATURAN PERUNDANG-UNDANGAN TENTANG KESEHATAN DI INDONESIA," DIPONEGORO LAW JOURNAL, vol. 6 (Program Studi S1 Ilmu Hukum, Fakultas Hukum, Universitas Diponegoro, August 18, 2017), https://ejournal3.undip.ac.id/index.php/dlr/article/view/17445.

${ }^{15}$ Endang Kusuma Astuti, Op. Cit., pg. 289.

${ }^{16}$ Carolina Kuntardjo, "Dimensions of Ethics and Telemedicine in Indonesia: Enough of Permenkes Number 20 Year 2019 As a Frame of Telemedicine Practices in Indonesia?," SOEPRA 6, no. 1 (April 30, 2020): 1-14, https://doi.org/10.24167/shk.v6i1.2606.
} 
in Article 7 Minister of Health Regulation No. 20 of 2019 concerning the Implementation of Inter-Health Telemedicine Services, which states that the health facilities providing consultation and the health facilities requesting consultation have the task of documenting telemedicine services in medical records.

\section{Responsibilities of the Professional Doctor in Telemedicine Services between Health Service Facilities}

The doctor's legal responsibility cannot be separated from the professional responsibility related to ethical and disciplinary issues. ${ }^{17}$

a. Ethical Dimensions

Medical ethics regulates that ethics that is used as the basis are the principles of bioethics, which consist of beneficence, non-maleficence, autonomy, and justice. So, doctors' responsiblity for running telemedicine services must be able to properly apply these bioethical principles. ${ }^{18}$

Ethical problems that often arise in telemedicine services between health care facilities include the lack of non-verbal communication and no direct physical examination of the patient. Compared to conventional health services, telemedicine services impose limits on non-verbal communication because most of the communication is done verbally (oral or written) and limits doctors to direct physical examinations. Simultaneously, non-verbal communication and direct physical examination play a role in the accuracy in establishing the diagnosis and determining the appropriate therapy.

It is essential to distinguish between pure and safe ethical violations, which are ethical and legal violations of telemedicine services between health facilities. A violation of pure ethics, for example, a specialist doctor charges a telemedicine consultation fee that is not reasonable for the health facilities that he/she works with, charges a consultation fee from his/her biological colleague or family, or without the knowledge and consent of a colleague takes over a patient who is not their right so that the doctor's actions are not legally prosecuted. However, it is necessary to get reprimand advice from professional organizations. Meanwhile, ethicolegal cases are violations that are not only against ethical issues but also against legal issues. For example, doctors provide sub-standard telemedicine services, leak medical secrets, commit threats or sexual harassment when consulting in services. ${ }^{19}$

\section{b. Discipline Dimensions}

In addition to doctors having to pay attention to legal and ethical issues, doctors must also pay attention to the medical profession's disciplinary issues related to doctors' adherence to the rules and regulations of the application of science in the implementation of medical practice. This aims to maintain and improve the quality of health services, provide protection to the community and maintain the medical profession's honor. ${ }^{20}$

Discipline violations can be committed by doctors in telemedicine services, such as a general practitioner teleconsulting a patient with a hernia to an internal medicine specialist who should do the teleconsultation to a surgeon. This incident indicates that the doctor

\footnotetext{
${ }^{17}$ Maskawati, Hukum Kesehatan, Yogyakarta: Litera, (2018), pg. 22.

18 Triwibowo, Cecep, Etika dan Hukum Kesehatan, Yogyakarta: Nuha Medika, (2014), pg. 45.

${ }^{19}$ Pukovisa Prawiroharjo, Peter Pratama, and Nurfanida Librianty, "Layanan Telemedis Di Indonesia: Keniscayaan, Risiko, Dan Batasan Etika," Jurnal Etika Kedokteran Indonesia 3, no. 1 (February 26, 2019): 1, https://doi.org/10.26880/jeki.v3i1.27.

${ }^{20}$ Nadia N. Sawicki, "Character, Competence, and the Principles of Medical Discipline," Journal of Health Care Law \& Policy 13 (2010), https://heinonline.org/HOL/Page?handle=hein.journals/hclwpo13\&id=289\&div=\&collection=.
} 
requesting consultation did not consult with the consultant doctor who has the appropriate competence. Another example is when the gynecologist at the City Hospital received a consultation from a general practitioner at the Village Health Center. However, the gynecologist delegated his work to perform a cesarean section to the general practitioner, who did not have the expertise to perform a cesarean section. In this condition, the delegation should be done to doctors who already have the competence to act, and also the delegation should be done in writing. ${ }^{21}$

The Indonesian Medical Council or Komisi Kedokteran Indonesia (KKI) has recently established a new regulation, namely the Indonesian Medical Council Regulation Number 74 of 2020 concerning Clinical Authority and Medical Practice through Telemedicine during the Pandemic Corona Virus Disease 2019 (COVID-19) in Indonesia. This regulation aims to provide additional clinical authority for doctors in carrying out professionalism according to their competence; improving the quality of health services, patient safety, and safety for doctors according to standards; and provide legal certainty for doctors in carrying out medical practice during the COVID-19 pandemic in Indonesia. Although the KKI has not made specific regulations regarding doctors' authority in telemedicine between health facilities, it is hoped that doctors who use telemedicine can follow the authority stipulated by KKI in this regulation to reduce the risk of violating medical discipline.

\section{Conclusion}

Based on the description above, doctors' responsibilities in telemedicine services between health facilities can be divided into legal responsibility (civil, criminal, and administrative) and professional responsibility (ethics and discipline). The doctor's responsibility in telemedicine services between health facilities is a doctor's obligation to be fulfilled for his actions. Under the Legal Responsibility Theory, responsibility is part of an obligation that must be fulfilled because obligations are none other than part of the duties carried out in a particular work environment. The legal principle used concerning legal accountability is that there will be no accountability without any action against the law.

\section{A. Book}

\section{Bibiliography}

Astuti, Endang Kusuma. 2009. Transaksi Terapeutik Dalam Upaya Pelayanan Medis di Rumah Sakit. Bandung: Citra Aditya Bakti.

Maskawati et al. 2018. Hukum Kesehatan. Yogyakarta: Litera

Munandar, Wahyudin Suganda. 2017. Hukum Kedokteran. Bandung: Alfabeta

Triwibowo, Cecep. 2014. Etika dan Hukum Kesehatan, Yogyakarta: Nuha Medika

\section{B. Journal}

Hadi, I Gusti Ayu Apsari. "PERBUATAN MELAWAN HUKUM DALAM PERTANGGUNGJAWABAN DOKTER TERHADAP TINDAKAN MALPRAKTIK MEDIS." Jurnal Yuridis 5, no. 1 (August 2, 2018): 98-133. https://doi.org/10.35586/.V5I1.318.

Hjelm, N. M. "Benefits and Drawbacks of Telemedicine." Journal of Telemedicine and Telecare. SAGE PublicationsSage UK: London, England, March 1, 2005. https://doi.org/10.1258/1357633053499886.

\footnotetext{
${ }^{21}$ Pukovisa Prawiroharjo et al., "Benarkah Dokter Spesialis Yang Tugas Jaga Pasti Melakukan Pelanggaran Etik Jika Sekedar Menjawab Konsul per Telepon Untuk Pertolongan Kegawatdaruratan?," Jurnal Etika Kedokteran Indonesia 2, no. 1 (March 19, 2018): 31, https://doi.org/10.26880/jeki.v2i1.13.
} 
Kuntardjo, Carolina. "Dimensions of Ethics and Telemedicine in Indonesia: Enough of Permenkes Number 20 Year 2019 As a Frame of Telemedicine Practices in Indonesia?" SOEPRA 6, no. 1 (April 30, 2020): 1-14. https://doi.org/10.24167/shk.v6i1.2606.

Kusuma Astuti, Endang. "TANGGUNG GUGAT DOKTER DAN RUMAH SAKIT KEPADA PASIEN PADA KEGAGALAN PELAYANAN MEDIS DI RUMAH SAKIT.” MasalahMasalah Hukum 40, no. 2 (April 19, 2011): 164-71. https://doi.org/10.14710/mmh.40.2.2011.164-171.

Mannas, Yussy A. "Hubungan Hukum Dokter Dan Pasien Serta Tanggung Jawab Dokter Dalam Penyelenggaraan Pelayanan Kesehatan.” Jurnal Cita Hukum 6, no. 1 (June 23, 2018): 163-82. https://doi.org/10.15408/JCH.V6I1.8274.

Meliala, Andreasta, Krishna Hort, and Laksono Trisnantoro. "Addressing the Unequal Geographic Distribution of Specialist Doctors in Indonesia: The Role of the Private Sector and Effectiveness of Current Regulations." Social Science and Medicine 82 (April 1, 2013): 30-34. https://doi.org/10.1016/j.socscimed.2013.01.029.

Njoto, Haryanto. "PERTANGGUNGJAWABAN DOKTER DAN RUMAH SAKIT AKIBAT TINDAKAN MEDIS YANG MERUGIKAN DALAM PERSPEKTIF UU No 44 Th 2009 TENTANG RUMAH SAKIT.” DiH: Jurnal Ilmu Hukum 7, no. 14 (August 1, 2011): 57-71. https://doi.org/10.30996/dih.v7i14.263.

Prawiroharjo, Pukovisa, Radi Muharris Mulyana, Prijo Sidipratomo, and Agus Purwadianto. "Benarkah Dokter Spesialis Yang Tugas Jaga Pasti Melakukan Pelanggaran Etik Jika Sekedar Menjawab Konsul per Telepon Untuk Pertolongan Kegawatdaruratan?" Jurnal Etika Kedokteran Indonesia 2, no. 1 (March 19, 2018): 31. https://doi.org/10.26880/jeki.v2i1.13.

Prawiroharjo, Pukovisa, Peter Pratama, and Nurfanida Librianty. "Layanan Telemedis Di Indonesia: Keniscayaan, Risiko, Dan Batasan Etika." Jurnal Etika Kedokteran Indonesia 3, no. 1 (February 26, 2019): 1. https://doi.org/10.26880/jeki.v3i1.27.

Ryu, Seewon. "Telemedicine: Opportunities and Developments in Member States: Report on the Second Global Survey on EHealth 2009 (Global Observatory for EHealth Series, Volume 2)." Healthcare Informatics Research 18, no. 2 (2012): 153. https://doi.org/10.4258/hir.2012.18.2.153.

Sawicki, Nadia N. "Character, Competence, and the Principles of Medical Discipline." Journal of Health Care Law \& Policy 13 (2010). https://heinonline.org/HOL/Page?handle=hein.journals/hclwpo13\&id=289\&div=\&collection=.

Scott Kruse, Clemens, Priyanka Karem, Kelli Shifflett, Lokesh Vegi, Karuna Ravi, and Matthew Brooks. "Evaluating Barriers to Adopting Telemedicine Worldwide: A Systematic Review." Journal of Telemedicine and Telecare. SAGE Publications Ltd, January 1, 2018. https://doi.org/10.1177/1357633X16674087.

Siringoringo, Valeri M P, Dewi Hendrawati, and R Suharto. "PENGATURAN PERLINDUNGAN HUKUM HAK-HAK PASIEN DALAM PERATURAN PERUNDANG-UNDANGAN TENTANG KESEHATAN DI INDONESIA.” DIPONEGORO LAW JOURNAL. Vol. 6. Program Studi S1 Ilmu Hukum, Fakultas Hukum, Universitas Diponegoro, August 18, 2017. https://ejournal3.undip.ac.id/index.php/dlr/article/view/17445.

Smith, V. J., A. Marshall, M. L.S. Lie, E. Bidmead, B. Beckwith, E. Van Oudgaarden, and S. C. Robson. "Implementation of a Fetal Ultrasound Telemedicine Service: Women's Views and Family Costs." BMC Pregnancy and Childbirth 21, no. 1 (December 1, 2021). https://doi.org/10.1186/s12884-020-03532-4.

Stanberry, Benedict. "Legal and Ethical Aspects of Telemedicine." Journal of Telemedicine and Telecare 12, no. 4 (June 1, 2006): 166-75. https://doi.org/10.1258/135763306777488825.

\section{Regulation}

Law Number 29 of 2004 concerning Medical Practice.

Law Number 24 of 2009 concerning the Flag, Language, and National Symbol and the National Anthem. 
Minister of Health Regulation Number 20 of 2019 concerning Implementation of Telemedicine Services between Health Service Facilities.

Indonesian Medical Council Regulation Number 74 of 2020 concerning Clinical Authority and Medical Practice through Telemedicine during the 2019 Corona Virus Disease Pandemic (COVID-19).

\section{Internet}

Biro Komunikasi dan Pelayanan Masyarakat Sekretariat Jenderal Kementerian Kesehatan RI. (2017). Menkes Soroti Masalah Maldistribusi Dokter Spesialis di Indonesia, available online from: https://www.depkes.go.id/article/print/17022400008/menkes-sorotimasalah-maldistribusi-dokter-spesialis-indonesia.html, diakses pada November 11, 2019. 
